\title{
Determination Of Factors Completion Thesis in Era Internet Of Think
}

\author{
Rahayu Retnaningsih ${ }^{1}$, Badrun Kartowagiran², Edi Istiyono ${ }^{3}$, Akbar Al Masjid ${ }^{4}$ \\ rahayu@ustjogja.ac.id; badrunkw@yahoo.com; edi_istiyono@uny.ac.id \\ Universitas Sarjanawiyata Tamansiswa, Yogyakarta, Indonesia ${ }^{1}$ \\ Universitas Negeri Yogyakarta, Indonesia ${ }^{2,3,4}$
}

\begin{abstract}
Research aims to effect of motivation to graduate on time, the ability to write has written works, the availability of learning resources, the quality of thesis guidance, and peer environment together towards completion. The method used is Correlation. The study population was a student of Mathematics Education Faculty of Education UST. They are collecting data using questionnaires. Experiments conducted by the research instruments used to test. Testing includes linearity test requirements analysis, test multicollinearity, and heteroscedasticity test. The data analysis technique used is a simple linear regression analysis and a double. The results obtained that: 1) Motivation to graduate on time no significant effect on the Thesis Final Project. The regression equation $\mathrm{Y}=8,069-0,116 \mathrm{X} 1$ Selanjutny; 2) Variable ability to write scientific papers did not significantly influence the TAS. The regression equation $\mathrm{Y}=2.204+0,046 \mathrm{X} 2 ; 3$ ) The variable quality of learning resources do not affect the TAS, the regression $Y=7,327-0,104 X 3$; 4) The variable quality of thesis no effect Significant guidance to TAS. Regression $\mathrm{Y}=2.927+0,026 \mathrm{X} 4$; and 5) peer environment variables significantly influence the TAS. Regression $\mathrm{Y}=-0.581+0,134 \mathrm{X} 5$ and 6) motivation to graduate on time, the ability to write scientific papers, the quality of learning resources availability, quality thesis guidance, peer environment that is equal to $\mathrm{Y}=12,398$ 0,033X1-0,104X2-0,225X3-0,065X4 + 0,202X5.
\end{abstract}

Keywords: Motivation Passed On Time, Scientific Writing Ability, Quality Learning Resources, Quality, and Completion Guidance, Thesis Final Project

\section{Intruduction}

Universities and colleges are required to maintain the quality of the learning process and improve the quality of its graduates to equip learners with the knowledge, skills, and attitudes[1], Students as intellectual candidates are obliged to improve themselves and the nation by studying a field of science for studying on campus. Then the knowledge that they control through the process of a college education should be implemented and applied[2], Not only are required to have knowledge and skills, but also the students are required to have a caring attitude towards the public. By helping people around, be a liaison between the government and society as well as a driver of change in the nation[3],

Philosophically founding of the UST Yogyakarta is the actual manifestation of Mental Tamansiswa as organizations struggle in the field of national and community through education in its broadest sense. This is the spirit of struggle does not know to stop (continuous), for the people and with the people, for all organizations, including the UST. The vision is; "Excelling in the glory and educating the nation (and excelling in the glory and the intellectual life of the nation)"

This vision has a strategic significance for the UST because it coincides with the momentum of the increasing number of new students that have occurred since the 2008/2009 academic year and must be addressed with institutional strengthening through various policies and services inspired by a clear vision and realistic. Apparently, due to the achievement of the 
vision have been implemented in stages starting from the strategic plan of consolidation until the idealization phase with timelines and measurable outcomes. Realistic because the vision was formulated by taking into account seriously the objective conditions of the institutional capacity of the present and future projections.

According to Ibn and Yoga[4], Indicators of success in achieving the vision of the first strategy include an increase in grade graduation, reduced the duration of the study, and increased speed to get a job. However, in practice, indicators of achievement of the vision's of UST Yogyakarta on the aspect of a long decline in the study are still experiencing problems. This is because there are many students at the UST Yogyakarta who have difficulty in completing the final project thesis for example at the Department of Mathematics Education.

In the learning process, the lecturer would expect that students can achieve maximum learning results. However, not a few found their learning difficulties experienced by students in the learning process such as the completion of the final thesis study results in this case the target has not been achieved an optimal pass. It is inevitable that in the learning process positively influenced by many factors. Regarding factors of learning difficulties, Muhammad Irham and Novan Ardy Wiyani[1] which states that the factors which can cause learning disabilities in students can be classified into internal factors and external factors.

Learning difficulties in the case of students who are taking courses in the final project thesis are feared would hinder his studies to be able to graduate on time or meet its target to pass more quickly as four years old.

Efforts are being made Mathematics Education Faculty of Teacher Training and Education (Guidance and Counseling) UST Yogyakarta to encourage the completion of student thesis by focusing on research methodology courses and seminars in order to the research-oriented thesis. Hopefully, the completion of the thesis can be reached in a short time with high-quality research results. By orienting the thesis of the research methodology courses and seminars, it is expected from the outset of the students already have plans to conduct thesis research and experience in methodology and seminars. So that students skilled in conducting thesis research.

\section{LITERATURE REVIEW}

A final project is a form of scientific papers prepared by the students of the study program based on the result of a problem that is done carefully with the guidance of lecturer. According to Dalman[5]thesis is a scientific work that presents the facts and reviews more specific topics and depth is a requirement to complete a degree program (undergraduate). Final Thesis (TAS) is a subject that must be taken for UST students who take the S1 and is one of the graduation requirements.

Demands in the thesis for students S1 is to carry out the research process in strict accordance with the rules which apply without having found and corrected theory been there (Ibn and Yoga[4], Thus, as long as students can take steps in research activities in the correct sequence and the final project thesis already qualified. This is in contrast with the demands of the final form of the thesis for students of S2. Thesis written S2 student is required to assess the existing theory with earlier theories or see the implementation of the theory in real life. Therefore, the level of difficulty in the execution of the thesis should be by the student's ability S1.

Sawas, a necessary and essential factor in the process of final thesis, is a system and service management thesis [4], System management and excellent service will be able to assist students in their thesis Final Settlement. According to Marshall and Paul[6] system is a series of two or more components that are interrelated and interact to achieve the objectives while 
according to Indonesian Dictionary[7] system is a device that is regularly elements interconnected to form a totality. The elements that exist within a system can consist of human resources, equipment, materials, procedures, and others. Management systems and services in final project thesis involved human resources consisting of faculty, staff, and students (Ibn and Yoga[4]). Faculty, staff, and students involved have the roles and duties of each in order to achieve the purpose of the final project thesis.

Other system and service management thesis final project, other elements that affect the process of final thesis is a final project thesis procedure. According to Indonesian dictionary is defined as the processing step procedure for completing an activity or method step by step precisely in solving a problem[7],

Prosedur in craft thesis is a series of activities/steps that involve multiple people/agencies and must be passed in order to complete the final project thesis (Ibn and Yoga[4]), Procedures in the final project thesis can be grouped in three parts. These parts are filing the title, the artistry, and the thesis examination. Each section has a requirement, the length of time required to complete, and the number of persons/institutions involved. The fewer requirements, the longer it takes, and persons/entities involved, the better for the final project thesis can still be achieved. As in the case of submission of thesis titles, if there is a rule that is sufficiently detailed and rigid like funds and quota titles that could be a barrier for students in completing the final project thesis because of the limitations of students and their desire to determine what will be examined.

Who has a close friendship which more typically brings a person to be more open to sharing many things in his close friend? Likewise, when students who are completing their thesis will be more open, to mutually motivate each other, and share knowledge to his close friends about the final thesis[8],

Berdasarkan description of the function Environment Peer disclosed above it can be concluded that the Environmental indicators Friends Sebayadapat saw from (1) The intensity of interactions; (2) A place to share knowledge, such as sharing knowledge about authorship of scientific work and research; (3) A place to share stories and motivate each other; and (4) Partners study and measure learning success.

\section{RESEARCH METHODS}

This research including the type of causal-comparative research. Causal-comparative research is a type of research in which research is conducted to determine the cause or reason of differences in behavior or status groups or individuals (Darmadi[9])[10], The approach used in this study is a quantitative approach. A quantitative approach is used to examine the numerical data that is processed and analyzed in the form of statistical analysis[11], i.e., on the questionnaire that was distributed about the factors that affect the completion of Final Thesis Student Mathematics Education Faculty of Teacher Training and Education (Guidance and Counseling) UST Yogyakarta,

The technique of collecting data that is used is using a questionnaire. Questionnaires were distributed to students of Mathematics Education Faculty of Teacher Training and Education (Guidance and Counseling) UST Yogyakarta directly in the Faculty of Education.

\section{RESULTS AND DISCUSSION}

The data obtained from the field are presented in the form of a data description of each variable, both independent variables, and the dependent variable. Analysis of these data includes the presentation of the Mean (M), median (Me), mode (Mo), Standard Deviation 
(SD), Frequency Distribution Table, Histogram, Table Categories tendency of each variable. The analysis used was multiple regression analysis and to test the hypothesis of the 1st, 2nd, 3rd, 4th, and fifth.

X1 - Y

\section{Coefficients}

\begin{tabular}{|c|c|c|c|c|c|}
\hline \multirow{2}{*}{ Model } & \multicolumn{2}{|c|}{$\begin{array}{c}\text { Coefficients } \\
\text { unstandardized }\end{array}$} & $\begin{array}{l}\text { standardized } \\
\text { Coefficients }\end{array}$ & \multirow[t]{2}{*}{$\mathrm{T}$} & \multirow[t]{2}{*}{ Sig. } \\
\hline & B & Std. Error & Beta & & \\
\hline $1 \quad$ (Constant) & 8.069 & 2,912 & & 2,771 & .018 \\
\hline $\begin{array}{l}\text { Motivation Passed } \\
\text { On Time }\end{array}$ & -.116 & .086 & -.377 & -1348 & .205 \\
\hline
\end{tabular}

a. Dependent Variable: Completion of Final Thesis

Regression coefficient, $\mathrm{a}=8.069$, constant number of unstandardized coefficients. This is a number that has meaning if there is no motivation to graduate on time (X1) then the consistent completion of a final thesis $(\mathrm{Y})$ is equal to 8.069 . $\mathrm{B}=-0.116$ is the number of regression coefficients. This means that each additional $1 \%$ is the level of motivation to graduate on time $(\mathrm{X} 1)$, the completion of the final project thesis $(\mathrm{Y})$ will rise by -0.116 . Then it can be concluded that if the regression coefficient (-), could mean that the motivation to graduate on time (X1) a negative effect on TAS $(\mathrm{Y})$. so that the regression equation is $\mathrm{Y}=$ $8.069-0,116 \mathrm{X} 1$. Hypothesis test to compare the value Sig is 0.05 . From the above output value of significance $(\mathrm{Sig})=0.205$ greater than the probability of 0.05 .

X2 - Y

Coefficients

\begin{tabular}{|c|c|c|c|c|c|}
\hline \multirow[t]{2}{*}{ Model } & \multicolumn{2}{|c|}{$\begin{array}{c}\text { Coefficients } \\
\text { unstandardized }\end{array}$} & $\begin{array}{l}\text { standardized } \\
\text { Coefficients }\end{array}$ & \multirow[t]{2}{*}{$\mathrm{T}$} & \multirow[t]{2}{*}{ Sig. } \\
\hline & B & Std. Error & beta & & \\
\hline $1 \quad$ (Constant) & 2,204 & 3,520 & & .626 & .544 \\
\hline $\begin{array}{l}\text { Scientific Writing } \\
\text { Ability }\end{array}$ & .046 & .083 & . 165 & .555 & .590 \\
\hline
\end{tabular}

a. Dependent Variable: Completion of Final Thesis

Regression coefficient, $\mathrm{a}=2.204$, constant number of unstandardized coefficients. This is a number that has meaning if there is the ability to write scientific papers (X2) the value of consistent completion of a final thesis $(\mathrm{Y})$ is equal to 2,204. $b=0,046$ is the number of regression coefficients. Then it can be concluded that if the regression coefficient $(+)$, could mean that the ability to write scientific papers (X2) has a positive influence on TAS (Y). so that the regression equation is $\mathrm{Y}=2.204+0.046 \mathrm{X} 2$. Hypothesis test to compare the value Sig is 0.05 . From the above output value of significance $(\mathrm{Sig})=0.590$ greater than the probability of 0.05 . This means that there is no effect of the ability to write scientific papers (X2) to TAS (Y). 
X3 - Y

Coefficients

\begin{tabular}{|cc|c|c|c|c|c|}
\hline \multirow{2}{*}{ Model } & \multicolumn{2}{|c|}{$\begin{array}{c}\text { Coefficients } \\
\text { unstandardized }\end{array}$} & \multicolumn{2}{|c|}{$\begin{array}{c}\text { standardized } \\
\text { Coefficients }\end{array}$} & \multirow{2}{*}{$\mathrm{T}$} & \multirow{2}{*}{ Sig. } \\
\cline { 2 - 5 } & \multicolumn{2}{|c|}{$\mathrm{B}$} & Std. Error & beta & & \\
\hline 1 & $\begin{array}{l}\text { (Constant) } \\
\text { Quality Learning } \\
\text { Resources }\end{array}$ & 7.327 & 3,970 & & 1,846 & .092 \\
& -.104 & .130 & -.235 & -.801 & .440 \\
\hline
\end{tabular}

a. Dependent Variable: Completion of Final Thesis

Regression coefficient, $\mathrm{a}=7.327$, constant number of unstandardized coefficients. This is a number that has meaning if there is no quality of learning resources (X3) then the consistent completion of a final thesis (Y) is equal to $7.327 \mathrm{~b}=-0.104$ is the number of regression coefficients. What this means is every additional $1 \%$ level quality learning resources quality learning resources (X3), the completion of the final project thesis $(\mathrm{Y})$ will rise by -0.104 . Then it can be concluded that if the regression coefficient $(-)$, can mean that the quality of learning resources (X3) an adverse effect on TAS (Y). So that the regression equation is $\mathrm{Y}=7.327$ to $0.104 \mathrm{X} 3$. Hypothesis test to compare the value Sig is 0.05 . From the above output value of significance $(\mathrm{Sig})=0.440$ more significant than the probability of 0.05 .

X4 - Y

Coefficients

\begin{tabular}{|l|l|l|l|l|l|}
\hline \multirow{2}{*}{ Model } & \multicolumn{2}{|c|}{$\begin{array}{c}\text { Coefficients } \\
\text { unstandardized }\end{array}$} & $\begin{array}{c}\text { standardized } \\
\text { Coefficients }\end{array}$ & \multirow{2}{*}{$\mathrm{T}$} & \multirow{2}{*}{ Sig. } \\
\cline { 2 - 5 } & \multicolumn{2}{|c|}{ B } & Std. Error & beta & \\
\hline $\begin{array}{l}\text { (Constant) } \\
\text { Quality Guidance } \\
\text { Thesis }\end{array}$ & 2,925 & 3,300 & & .886 & .394 \\
\hline
\end{tabular}

a. Dependent Variable: Completion of Final Thesis

Regression coefficient, $\mathrm{a}=2.927$, constant number of unstandardized coefficients. This is a number that has meaning if there is no quality guidance thesis (X4) then the consistent completion of a final thesis (Y) is equal to $2.927 \mathrm{~b}=0.026$ is the number of regression coefficients. What this means is every additional $1 \%$ level of quality guidance thesis (X4), the completion of the final project thesis (Y) will rise by 0,026 . Then it can be concluded that if the regression coefficient $(+)$, could mean that the quality of the guidance thesis (X4) effect on TAS (Y). so that the regression equation is $\mathrm{Y}=2.927+0.026 \mathrm{X} 4$. Hypothesis test to compare the value Sig is 0.05 . From the above output value of significance $((\mathrm{Sig})=0.716$ greater than the probability of 0.05 . 
X5 - Y

Coefficients

\begin{tabular}{|c|c|c|c|c|c|}
\hline \multirow[t]{2}{*}{ Model } & \multicolumn{2}{|c|}{$\begin{array}{c}\text { Coefficients } \\
\text { unstandardized } \\
\end{array}$} & $\begin{array}{l}\text { standardized } \\
\text { Coefficients } \\
\end{array}$ & \multirow[t]{2}{*}{$\mathrm{T}$} & \multirow[t]{2}{*}{ Sig. } \\
\hline & B & Std. Error & beta & & \\
\hline $1 \quad$ (Constant) & -.581 & 1,682 & & -.346 & .736 \\
\hline $\begin{array}{l}\text { Environmental } \\
\text { Peers }\end{array}$ & .134 & .047 & .649 & 2,831 & .016 \\
\hline
\end{tabular}

a. Dependent Variable: Completion of Final Thesis

Regression coefficient, $\mathrm{a}=-0.581$, constant number of unstandardized coefficients. This is a number that has meaning if there were peer environment (X5) then the consistent completion of a final thesis $(\mathrm{Y})$ is approximate $-0.581 \mathrm{~b}=0.134$ is the number of regression coefficients. What this means is every additional $1 \%$ level peer environment (X5), the completion of the final project thesis $(\mathrm{Y})$ will rise by 0.134 . Then it can be concluded that if the regression coefficient (+), could mean that the peer environment (X5) effect on TAS (Y). so that the regression equation is $\mathrm{Y}=-0.581+0.134 \mathrm{X} 5$. Hypothesis test to compare the value $\mathrm{Sig}$ is 0.05 . From the above output value of significance $(\mathrm{Sig})=0.016$ smaller than the probability of 0.05 . This means that there is the effect of peer environment (X5) to TAS (Y).

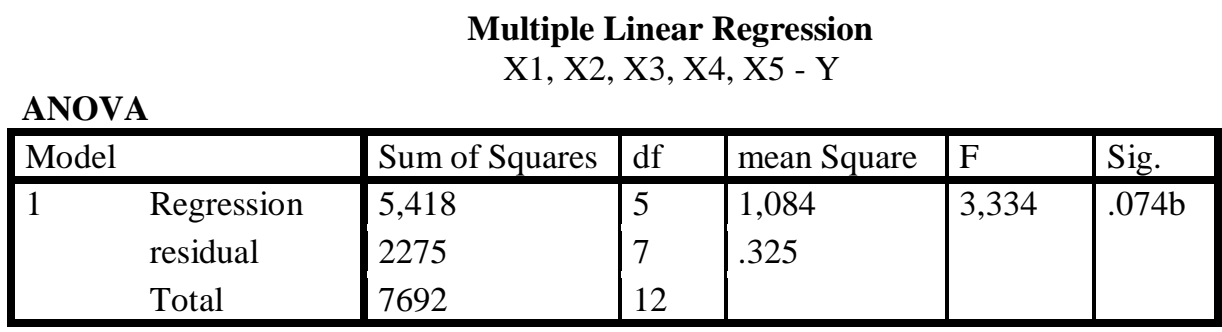

a. Dependent Variable: Completion of Final Thesis

b. Predictors: (Constant), Motivation Passed On Time, Scientific Writing Ability, Quality Learning Resources, Quality Guidance Thesis

From the above output, Sig.F value of 0.074 ( $p>0.05$ ) means that the hypothesis is rejected that the variables of motivation, peer environment, the ability to write, quality guidance, the quality of learning resources do not significantly influence the TAS.

From the results obtained when analyzed either by simple regression and multiple linear regression can be concluded that the higher the motivation to graduate on time, the better the ability to write scientific papers, the higher the quality of learning, the higher the quality of the guidance of the thesis, the faster the Final task Thesis and peer environment, the better, the longer it takes to work on Final Thesis.

We are observing these conditions of so many specific issues that grow in the field with an unexpected condition. So we need further research to highlight the problem deeper and sharper. As was assumed in the initial hypothesis if the provision of learning motivation and maximizing the availability of adequate learning resources will affect the completion of the process of making up the thesis so that students can complete studies to graduate on time. 


\section{Bibliography}

[1] M. dan N. A. W. Irham, Psikologi Pendidikan. Yogyakarta: Ar-RuzzMedia, 2014.

[2] M. N. Purwanto, Psikologi Pendidikan. Bandung: PT RemajaRosdakarya, 2017.

[3] Iskandar, Psikologi Pendidikan Sebuah Orientasi Baru. Jakarta: Gaung Persabda, 2009.

[4] I. and Y. G. S. Siswanto, "Faktor-Faktor Penghambat Penyelesaian Tugas Akhir Skripsi Mahasiswa Pendidikan Teknik Otomotif FT UNY," E-Joernal FT UNY Yogyakarta, 2013.

[5] Dalman, Menulis Karya Ilmiah. Jakarta: PT Raja grafindo Persada, 2014.

[6] M. dan P. J. S. Romey, Sistem Informasi Akuntansi: Accounting Information System. Jakarta: Selemba Empat, 2011.

[7] W. J. S. Poerwadarminta, Kamus Umum Bahasa Indonesia Edisi Ketiga. Jakarta: Balai Pustaka, 2007.

[8] J. W. Santrock, Child Development. Eleventh edition. Boston: McGraw-Hill, 2007.

[9] H. Darmadi, Metode Penelitian Pendidikan. Bandung: Alfabeta, 2011.

[10] L. Moleong, Metodologi Penenlitian Kualitatif. Bandung: PT RemajaRosdakarya, 2007.

[11] Sugiyono, Metode Penelitian Kuantitatif, Kualitatif dan R\&D. Bandung: Alfabeta, 2009. 